\title{
Szakmatörténeti kuriózum Érden: Egyed László földtágulási modellje Kádár László hagyatékából
}

\author{
Márton Mátyás
}

DOI: $10.30921 / G K .72 .2020 .6 .1$

Absztrakt: Igazi szakmai kuriózumot, magyar földtudomány-történeti érdekességet rejt az érdi Magyar Földrajzi Múzeum gyújteménye. A debreceni egyetem adományozta a Múzeumnak 1994-ben a Kádár László hagyatékából származó 13 darabból álló sajátos földgömbsorozatot, amely különbözó átmérôjü glóbuszokból áll. Olyan földgömbök ezek, amelyek átmérôje glóbuszról glóbuszra nô, és amelyeken a kontinenseket eltérô helyzetekben ábrázolta a modell szerkesztôje Földünk felszinén. Az egykor volt Kossuth Lajos Tudományegyetem Földrajzi Tanszékének vezető professzora, Kádár László irányításával született a földgömbsorozat, amely Egyed László, az Eötvös Loránd Tudományegyetem Geofizikai Tanszékének vezetố professzora által megalkotott, világszerte ismert földtágulási elmélet szemléltetésére született. Szakmatörténeti érdekesség, hogy Kádár professzor akkor készítette (készíttette) ezt a glóbuszsorozatot (és ennek személyes érintettje voltam), amikor az új globális tektonikai elmélet, a lemeztektonika, már egyre inkább elfogadottá vált...

Dolgozatom egyben tisztelgés a korán elhunyt tudós geofizikus, Egyed László elótt, halálának 50. évfordulóján és emlékezés a neves kortársakra, az 1970-es évek nagy földtudományi korszakváltásának idején.

Abstract: The collection of the Hungarian Geographical Museum in Érd hides a real professional curiosity and a historical interest in Hungarian earth sciences. In 1994, the University of Debrecen donated a special series of 13 globes consisting of globes of different diameters from the legacy of László Kádár to the Museum. The diameter globes increases from globe to globe, and the continents were represented on them in different positions by the model editor on the surface of our Earth. The series of globes, made under the leadership of László Kádár, professor of the Department of Geography at the former Kossuth Lajos University, was created to illustrate the world-renowned theory of earth expansion developed by László Egyed, the leading professor of the Department of Geophysics at Eötvös Loránd University. It is interesting from the point of view of Hungarian history of earth sciences that Professor Kádár made this series of globes (and I was personally involved in it) when the new global tectonic theory, plate tectonics, became more and more accepted...

This paper is also a tribute to the early deceased scientist geophysicist László Egyed, on the 50th anniversary of his death, and a memory of famous contemporaries at the time of the great change in the earth sciences of the 1970 s.

Kulcsszavak: kontinensvándorlás, földtágulás, lemeztektonika, modellföldgömbök

Keywords: continental drift, slow expansion of the Earth, plate tectonics, model globes

\section{Bevezetés}

Puskás Katalin restaurátorral, az érdi Magyar Földrajzi Múzeum gyújteménykezelójével, az 1970-es évek végi magyar földtudományi trendekrôl folytatott beszélgetés során került szóba Stegena Lajos professzor úr mint olyan tanárom, aki mindkét szakomon tanított engem, és mindkét diplomamunkám irányítója is volt. Szó szót követett, képbe jött Egyed László mint elsố tanszékvezetôm az ELTE Geofizikai Tanszékén, az ô földtágulási elmélete és ennek kapcsán Kádár László professzor tervezett, a földtágulást bemutató földgömbsorozata. És akkor jött a meglepetés, mert Kati közölte, hogy ezeket a glóbuszokat a Múzeumban ôrzik...

Meg is nézhettem a raktárban lévô állványon sorakozó földgömböket. Kézbe véve ezeket felidézôdtek az 1970-es évek történései.

\section{Egy kis (személyes) földtudományi szakmatörténet}

Az 1970-es években a „két lábon álló” Kartográfiai Vállalat állandó munkaerőhiánnyal küzdött a geodézia és a geokartográfia területén is, így az egyetlen, felsôfokú kartográfus utánpótlást biztosítani hivatott ELTE Térképtudományi Tanszékén végzettek mellett örömmel alkalmaztak a rokon tudományterületeken diplomát szerzett munkatársakat (földrajztanár szakot, geológiát vagy akár geofizikát végzetteket) is. Magam is így kerültem a vállalathoz, geofizikusként, ahol a kartográfus tanulmányaim - levelezô hallgatóként történô - befejezését támogatták.

1974-ben szereztem geofizikus, 1975-ben kartográfus oklevelet. Geofizikából „A Pannon-medence tektonikája” címmel készítettem a diplomamunkámat (Márton 1974) Stegena Lajos professzor és Horváth Ferenc adjunktus irányításával. Történetünk szempontjából ez azért fontos, mert mindketten „lemeztektonika-hívôk" voltak, és én a tanítványuk lehettem. Részt vehettem hármuk - Géczy Barnabás professzorral közösen tartott - szakmai megbeszélésein, követve készülố tanulmányaik, szakcikkeik megszületését, ilyen módon igazi, egészen szoros tanár-diák kapcsolat részesévé váltam, ami jelentôsen hozzájárult a választott témában történô elmélyülésemhez. Egyik oka lehetett ez annak is, hogy 1975-ben „Geofizikai földgömbök szerkesztése" címmel született meg a kartográfusi diplomamunkám (Márton 1975). Témavezetôim Stegena Lajos és Barta György professzorok (de igazi irányítóm és segítôm azonban Füsi Lajos adjunktus) voltak. 
„A gömbi ábrázolás - írja Barta György egyik 1966-os kéziratában - elôsegíti a különbözô geofizikai jelenségek kapcsolatainak közvetlen, empirikus felismerését. Megszúnik a különböző térképi vetítések során mindig fellépô torzítások zavaró hatása, és ezáltal az egyes anomáliák és jelenségek méretszerú összehasonlítása is lehetôvé válik.

Gömbi ábrázolásban jobban érvényesül a geofizikai folyamatok anyaghoz kötöttsége, az így szemlélt adatrendszerek alapján kialakítható földmodell testszerúbbé válik. A feltételezhető változásjelenségek (kontinensvándorlások és viszonyított elfordulások, pólusmozgások) nyomán fellépô erốrendszerek, feszültségek és az ezzel kapcsolatos tektonizmus reálisabban vizsgálható.

A mágneses és gravitációs erôterek különbözô sajátságait képviselô izovonalak természetes lefutását jobban lehet így szemlélni, és az ebból származó elônyöket a Földdel kapcsolatos tudományok oktatásában is jól fel lehet használni."

E szemlélet ismeretében teljesen érthetô, hogy miért született 1967 ben a Térképtudományi Tanszéken egy Barta-Füsi-féle múanyag geofizikai földgömb (Barta 1966, Füsi 1973, Márton 1975) (1. ábra), aminek látványa mindig izgatott már geofizikustérképész szakos hallgató koromban is, hiszen napi „vendége” voltam mindkét - egyébként az egykori Ludovika épületének második emeletén éppen szemben fekvő - tanszéknek.

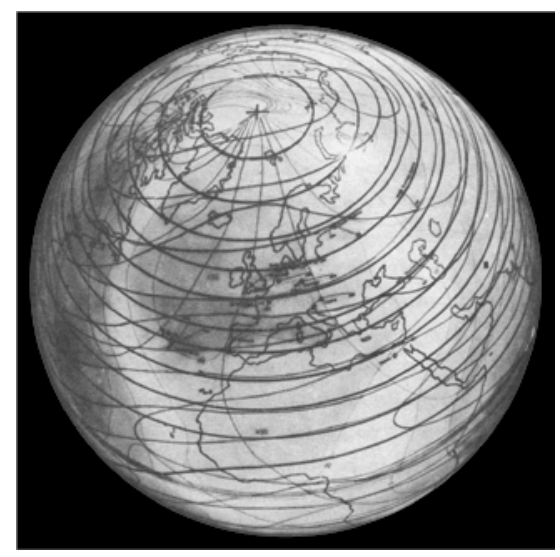

1. ábra. $50 \mathrm{~cm}$ átmérôjú geofizikai földgömb 1967-bôl. (Egyedi példány: Barta György és Füsi Lajos munkája. ELTE Térképtudományi és Geoinformatikai Intézet)
Tanulmányaim idején, az 1970-es évektôl kezdôdôen egyébként Füsi Lajos vezetésével kísérletek folytak műanyag földgömbök előállítására (sorozatgyártására) a Térképtudományi Tanszéken, amelyekbe hallgatókat is bevontak (Olajos 1974, Márton 1975).

Füsi tanár úr, atyai szeretettel igazgatta a hallgatók tanszéki munkáját, de követte szakmai életútjukat a diploma megszerzése után is. Többször járt hallgatókkal a Kartográfiai Vállalatnál, hogy a nagyüzemi térképgyártást megismerhessék, hiszen a vállalatnál a térképkészítés teljes vertikumát át lehetett tekinteni, a térképszerkesztés, -tervezés elsô lépéseitől kezdve a tisztázatirajz-készítés, a litográfia, a nyomdai előkészítés fázisain át egészen a térkép-sokszorosításig. Amikor már a vállalat térképszerkesztôje voltam, minden alkalommal felkeresett, ha a Szerkesztô Osztályon folyó munkával ismerkedtek a hallgatók, akkor is, ha éppen nem én adtam arról tájékoztatást, és a néhány perces beszélgetés során tájékozódott „szakmai hogylétemrôl”. Egy alkalommal (1976ban) jelezte, hogy a Kossuth Lajos Tudományegyetem professzora, Kádár László látogat el a Térképtudományi Tanszékre, és szeretne találkozni velem. Kiderült, hogy Füsi Lajos tanár úr beszámolt neki a tanszéken folyó múanyag földgömbös kutatásokról, és ennek kapcsán szóba került a kartográfusi diplomamunkám, a „Geofizikai földgömbök szerkesztése”. Így Kádár, Füsi javaslatára tárgyalt velem a Térképtudományi Tanszéken az általa elképzelt, a Föld tágulását és ennek következtében a földfelszín változását bemutató földgömbsorozat elkészítésérôl. Eredményes megvalósítás esetére azt az ajánlatot kaptam, hogy a munkát részletesen leíró, a célját bemutató dolgozat elkészítése és benyújtása lehetôvé teszi számomra az egyetemi doktori cím elnyerését is. (Ekkor még nem kellett szigorlati és nyelvvizsgákat tenni, illetve nyilvános védést tartani. A dolgozatot egy bizottság bírálta el, és adta vagy nem adta meg a címet.)

Ajtay Ágnes (osztályvezetôm a Kartográfiai Vállalatnál) támogatta a projektet, jelezte azt is, ha sikeres lesz a munkám, talán hasznosíthatók lesznek az eredmények a vállalati földgömbgyártásban is. Ám Stegena Lajos professzor úr keresztülhúzta számításunkat, egy idôre meghiúsítva ezzel tudományos ambícióimat: „Maga lemeztektonikát hallgatott az ELTE-n, a Pannon-medence tektonikájából írta diplomamunkáját, nem vállalhatja fel ilyen túlhaladott elmélet támogatását." Ellenérveimre, melyek szerint Egyed földtágulási elmélete nemzetközi szinten ismert, és igen jelentôs, széles körû szakmatörténeti érdeklődésre tarthat számot földgömbsorozaton történó bemutatása, valamint hogy szerintem a lemeztektonika múködése végsố soron nem zárja ki a földtágulás elméletét, nem enyhült meg a profeszszor úr. Sôt! Az utóbbi megjegyzésem valószínúleg sokkoló lehetett, mert haragos válasza így hangzott: „Akkor menjen doktorálni Debrecenbe!” Megjegyeztem, hogy mindkét diplomámat a professzor úr vezetésével szereztem az ELTE-n, és ha valahol, akkor itt kívánok doktorálni is. [Erre is sor került, de csak majd' 10 évvel késôbb. Három szigorlati és egy nyelvvizsga letétele után nyilvános védésen szereztem meg a doktori címet Stegena Lajos professzor vezetésével, „Az óceánés tengerfenék domborzata. Tenger alatti felszínek ábrázolása kisméretarányú térképeken" címmel elkészített dolgozatommal (Márton 1985), amelyben már árnyaltabban foglaltam állást a kritikus kérdésben: „... következik - ha a Föld deformálódását és ilyen nagyságrendú tágulását [29] kizárjuk -, hogy az így keletkezô óceánfenéknek (vagy legalább jelentôs részének) valahol vissza kell kerülnie a földköpeny mélyebb régióiba, pontosabban az asztenoszférába." És a lábjegyzetben: »[29] Kisebb mérvú földtágulás a lemeztektonika „múködése" szempontjából közömbös. Mivel a lemeztektonikai folyamatok múködnek, a fenti nagyságrendú horizontális elmozdulásokat létrehozó mértékú földtágulás kizárható!« De ez már egy másik történet...]

Így nem lehettem részese annak a munkának, ami végül mégis megvalósult, amelynek eredménye ma már az érdi Magyar Földrajzi Múzeum gyưjteményét gazdagítja, és amelynek nyomára egy szakmatörténeti 
beszélgetés során egészen véletlenül bukkantam, Puskás Katalinnak köszönhetôen.

\section{A történet szereplói (megemlékezés)}

Mai olvasóink többsége már nemigen ismeri az elôzốekben ismertetett történet szereplôit. Ezért néhány szóban érdemes megemlékezni róluk.

Egyed László (1914-1970) „Kossuth-díjas akadémikus, az ELTE TTK dékánja, valamint Geofizikai Tanszékének vezetôje... Egyed Lászlót mint kutatót, a maga idejében a nemzetközi geofizikai közvélemény a lassú expanziós elmélet vezetố exponenseként ismerte meg és ünnepelte. ...munkásságának zömét azok a kutatások teszik ki, amelyek a Föld tágulását voltak hivatottak bizonyítani... Széleskörú nyelvtudását felhasználva, elméletét számos konferencián ismertette, illetve különbözô külföldi akadémiák meghívására róla elôadásokat tartott. Elismertségét mutatja, hogy beválasztották a COSPAR héttagú ${ }^{1}$ elnökségébe. A Magyar Tudományos Akadémia 1960-ban levelező, 1970-ben pedig rendes tagjává fogadta" (ELTE-01).

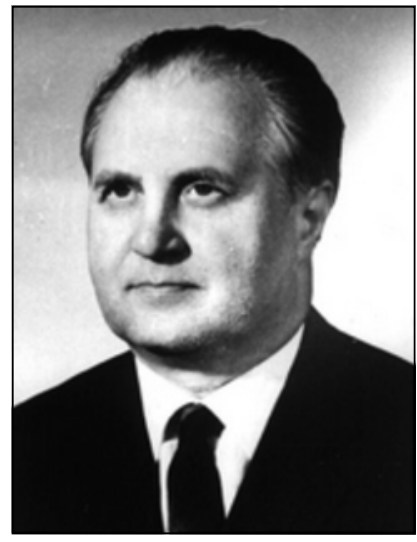

Egyed László

Kádár László (1908-1989) „földrajztudós, a földrajzi tudományok doktora (1956). Háromszéki székely család sarja... 1945-ben a debreceni tudományegy. Földrajzi Intézetének vezetóje, a földrajz tanszék vezetô professzora. 1948-49-ben a Bölcsészettudományi Kar prodékánja, 1951-52-ben a Természettudományi Kar dékánh.-e, 1952-54 között

1 Nemzetközi Ưrkutatási Bizottság dékánja, 1954-55-ben pedig az egy. rektora. A folyóvíz és a szél munkájának sokoldalú tanulmányozása alapján az 1960-as évek közepére egy általános földfelszín fejlôdési rendszert dolgozott ki, kimunkálta a földi légkörzés új modelljét is, majd 1966-ban elvégezte a futóhomokformák genetikus rendszerezését. 1971-ben jelent meg az a szintézise, amely a folyóvíz által létrehozott formák teljes genetikus rendszerét adta. Új megállapításokat tett a Magyar-medence negyedidőszaki feltöltôdésével kapcsolatban is. Sokat foglalkozott a földkéreg fejlődésével, a kontinensek és óceánok kialakulásával, a hegységképződések, a jégkorszakok kérdésével, a Föld őséghajlati viszonyainak tanulmányozásával, a Föld tágulásával, a hideg földkeletkezési elmélettel. Nyugalomba vonulása után Kôrösi Csoma Sándor életmúvének továbbtanulmányozásával foglalkozott, és a családi örökségbe kapott kovásznai házát Kórösi Csoma Sándor emlékmúzeum céljára felajánlotta a román államnak" (Kenyeres 1994).

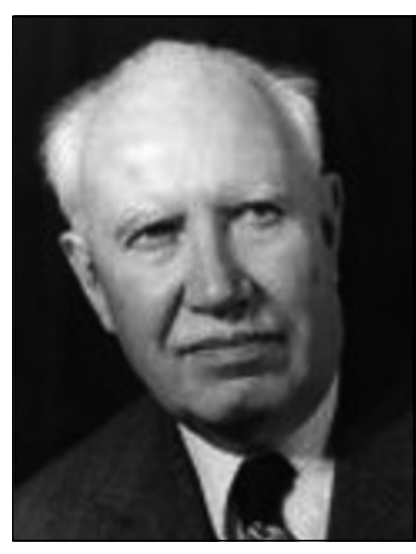

Kádár László

Stegena Lajos (1921-1997) „az Eötvös Loránd Tudományegyetem nyugalmazott egyetemi tanára... Egyetemünkkel 1953 óta állt kapcsolatban. A geofizika egyetemi tanára 1963-ban lett. 1966-1987 között, 21 évig a Térképtudományi Tanszék vezetôje, 1975-1984 közötti években a Földtudományi Szakbizottság elnöke, majd 1987-ig a Környezetfizikai Tanszékcsoport vezetôje volt. Több évtizeden keresztül geofizikus és térképész tárgyakat oktatott. Kutatói munkásságát a Kárpát-medence geonómiai megismerése és megismertetése terén kifejtett másfélszáz tudományos publikáció és külföldi egyetemek vendégprofesszori felkérései bizonyítják..." (ELTE-02).

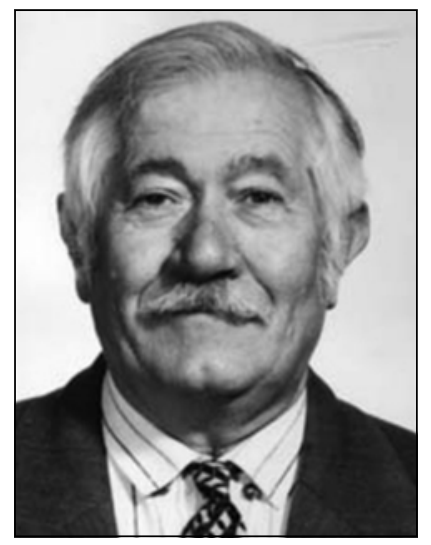

Stegena Lajos

Géczy Barnabás (1925-) „Széchenyi-díjas paleontológus, egyetemi tanár, az ELTE emeritus professzora, az MTA rendes tagja. A paleoökológia és a kréta idôszaki korallok ôstörténetének neves kutatója. Diplomájának megszerzése után, 1947-ben az egyetem őslénytani tanszékén kapott munkatársi állást. 1954től adjunktusként, 1964-től egyetemi docensként dolgozott. 1967-ben vette át egyetemi tanári kinevezését. 1973ban megbízták a paleontológiai tanszék vezetésével. 1995-ben vonult nyugdíjba. 1982 és 1983 között a párizsi Curie Egyetem (Sorbonne VI.) vendégprofesszora volt. Kutatásai során a lemeztektonika módszereit alkalmazta, elsôsorban a jura ôsföldrajzi helyzet rekonstruálása során, amelynek ammonitesz-faunákat alkalmazott. Egyéb kutatásokat végzett a paleobiográfia és a paleoevolúció terén." (Wikipédia-02).

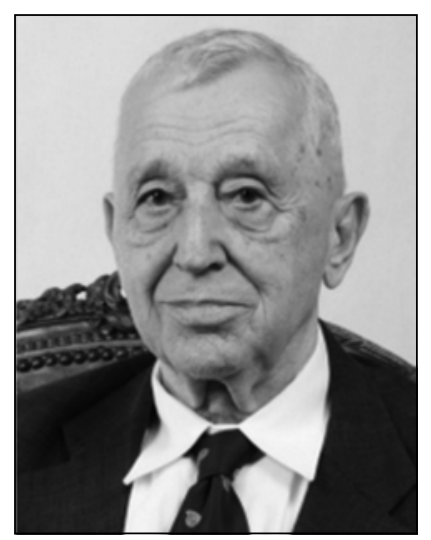

Géczy Barnabás 
Horváth Ferenc (1944-2018) „geofizikus, az MTA doktora, egyetemi tanár, az ELTE emeritus professzora. Fô kutatási területe a geodinamika és a szénhidrogénkutatás, úttörő szerepe volt (Stegena Lajossal és Géczy Barnabással) a Pannon-medence lemeztektonikai modelljének kialakításában. A geodinamika, a neotektonika és a medencefejlôdés egyik legelismertebb hazai múvelôje. Iskolateremtô kutató és oktató, jelenleg is a legidézettebb magyar földtudományi szakember... Elsố és egyetlen munkahelye az Eötvös Loránd Tudományegyetem Geofizikai Tanszéke és az itt múködő ELTE-MTA kutatócsoport. 1967-tôl a tanszéken tanársegéd, 1973-tól adjunktus, majd 1974-tôl 1999-ig kutatói állományban volt: a kutatócsoportban elôbb tudományos munkatárs, majd 1988-tól tudományos főmunkatárs. Ismét oktatói státuszba kerülve 1994-ben docens, 1999-ben egyetemi tanár lett. 2000-2008 között a tanszék vezetóje. Emellett 2005-ben a TTK átszervezésekor három tanszékcsoportból újonnan megalakult Földrajz- és Földtudományi Intézet elsố igazgatója is lett, ezt a tisztségét 2007-ig töltötte be. 2013-ban a Geofizikai Tanszék emeritus profeszszora lett" (Wikipédia-01).

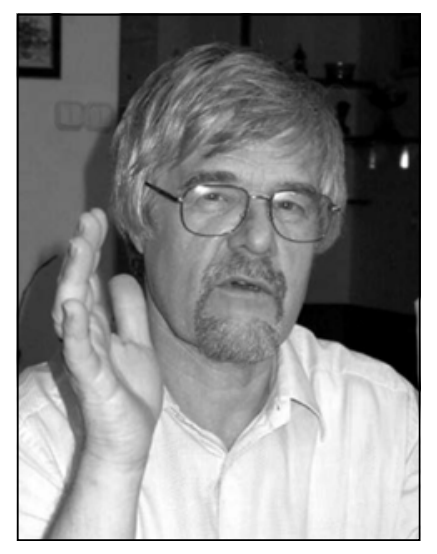

Horváth Ferenc

Barta György (1915-1992) „akadémikus 1971-tôl haláláig az Eötvös Loránd Tudományegyetem Geofizikai Tanszékének egyetemi tanára volt, és 14 évig, 1971-1985 között a tanszék vezetôje... A Föld mágneses és gravitációs erôterének vizsgálata volt igazi szakterülete egész élete során... A sok évig tartó mérési tevékenység mellett kezdte meg elméleti tudományos tevékenységét. A világ földmágneses ... obszervatóriumai adatsorainak elemzése vezette - a világon elsôként - a mágneses tér 50 év körüli periódusidejű szekuláris változásának felismerésére. Kutatói tevékenysége középpontjában ennek a jelenségnek a minél pontosabb megismerése állt, beleértve a jelenség okainak keresését, és a más földi erôterekkel lehetséges kapcsolat vizsgálatát. A hatvanas évek közepén, az elsô múholdas adatrendszerek megjelenése után a Föld alakjára vonatkozó ismeretek hirtelen sokasodása nyitott számára új utakat a földi erôterek vizsgálatára. A geoid finom részleteinek megismerése tette lehetôvé a gravitációs évszázados változás és a földi erôterek kapcsolatának vizsgálatát. Kutatási eredményeirôl közel háromszáz publikációt jelentetett meg az évtizedek során, köztük két könyvet" (ELTE-03).

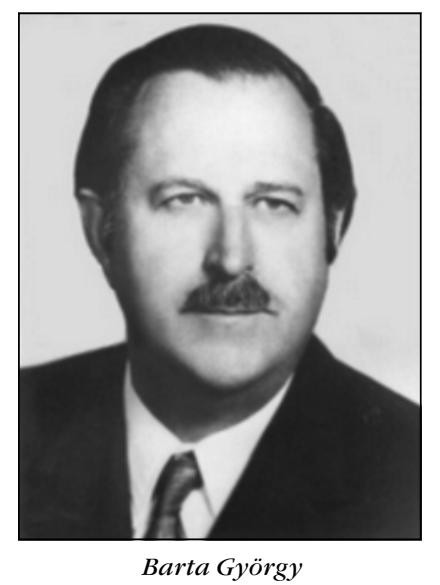

Füsi Lajos (1920-1999) ”az Eötvös Loránd Tudományegyetem Térképtudományi Tanszéke megbecsült és kezdettől fogva igen tevékeny oktatója, nyugalmazott docense..., élete összeforrt a tanszék létrehozásával, kiépítésével és hosszú idô óta sikeres múködésével. Turner Istvánnal, a neves földgömbkészítôvel 1953-tól a 11, 20, 25 és $40 \mathrm{~cm}$ átmérôjû fizikai és politikai glóbuszok kartografálásában (névrajzának kidolgozásában) személyesen is részt vett. Ezzel közelkerült az 1953ban megalakult Térképtudományi Tanszékhez, ahol elôbb külsố munkatárs, majd tanársegéd lett (1954)
Irmédi-Molnár László professzor mellett. ...sikerült a tanszéken és oktatási tevékenységében olyan családias légkört kialakítani, amely azt baráti és tudományos múhellyé tette tanárok és hallgatók számára egyaránt. A földgömbökkel kapcsolatos kutatásait 1966-ra egyetemi doktori disszertációvá érlelte, létrehozva 1961-ben egy 1:10 milliós méretarányú $110 \mathrm{~cm}$ átmérôjū domborföldgömböt. „Az elsô magyar dombormúvú múanyag földgömb" címú disszertációjához pedig $212 \mathrm{~cm}$ átmérôjû́ (1:6 milliós) dombormúvú átvilágítható kettôs földgömböt szerkesztett. Utóbbihoz maga kísérletezte ki a múanyagok felhasználhatóságát és az erre történô szerkesztési módszereket (Füsi 1970, 1973 - MM)... Különös érzékkel munkálkodott a térképészet interdiszciplináris területein... Munkatársai, tanítványai szeretettel emlékeznek baráti és atyai egyéniségére valamint a tanszék múködése érdekében kifejtett tevékenységére« (ELTE-04).

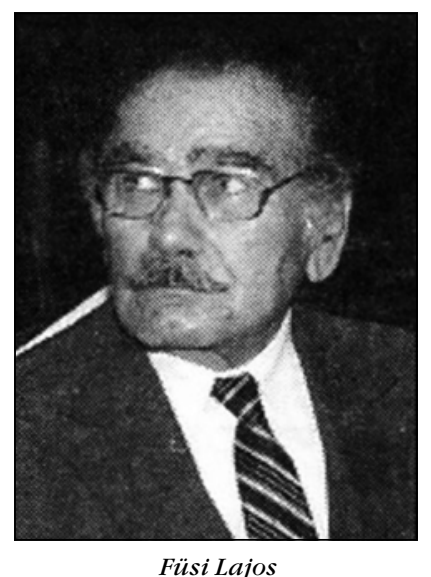

\section{A kontinensvándorlástól a kozmológiai földmodellig}

Nem tekinthetem feladatomnak, hogy az Egyed-életmú témánk szempontjából akár csak szúkebben vett fejlődését is elemezzem, amelyet - Balkay Bálint (1979) Egyednek a geotektonika tudományához való hozzájárulását elemzô tanulmányának nyomán - röviden úgy foglalhatunk össze, hogy a Wegenerelmélettôl a kozmológiai földmodellig terjed. „Ismeretes, hogy a kontinensvándorlást a geológusok és geofizikusok 1926-ban véglegesen elvetették (Symposium on Continental 
Drift, 1926. november 15., New York, American Association of Petroleum Geologists). Közel 30 év elteltével az elsố paleomágneses eredmények (Blackett és Runcorn) független bizonyítékot szolgáltattak rá, és 1967-tôl kezdve szinte senki nem kételkedik benne (Márton 1981). Egyed azonban már az '50-es években „mélyreható kutatásokat végzett a Wegenerelmélettel kapcsolatban, és végül azok eredményeiból elindulva jutott el a földtágulás gondolatához" (Balkay 1979).

Balkay az általa öt fejezetre osztott életmú két utolsó korszakát így jellemzi:

»Negyedik korszakának (19551957) kiemelkedô eseménye a föld tágulásának eszméjén alapuló „új földmodell" meghirdetése volt: az eszme akkori és késôbbi fogadtatásától függetlenül Egyed Lászlót voltaképpen e teljesítménye alapján soroljuk a geotektonika alkotó egyéniségei közé. E korszakában földtágulási elméletét még a klasszikus fizikára alapozta.

Végül ötödik korszaka 1957-tôl 1970-ben bekövetkezett haláláig tartott; a kozmológiai földmodell korszaka ez, amikor a Föld tágulását már nem a klasszikus fizikából, hanem a relativisztikus kozmológia bizonyos eredményeiból kísérelte meg levezetni."

„Egyed Lászlót joggal tekinthetjük a magyar geotektonika atyjának akkor is, ha a geotektonika tudományának mai magyar múvelói a korszellemnek megfelelóen egészen más irányban haladnak. Egyed Lászlót méltán tarthatjuk... az egyetemes geofizikai gondolkodás egyik kiemelkedô, színes, eredeti és némiképp tragikus sorsú alkotó egyéniségének is" (Balkay 1979).

Hasonlóan pozitív értékelést találhatunk Barta György (1978) korábbi tanulmányában is: „Magyarországon globális jellegú szemléleti változást okozott Egyed László földtágulási elmélete, amellyel egy sor földfizikai jelenséget az addiginál jobban meg tudott magyarázni, sốt a fizika és csillagászat vonatkozásaiban is feltárt bizonyos kapcsolódási lehetôségeket. Az elmélet legfontosabb eredménye azonban kétségtelenül az volt, hogy a zsugorodó Föld paszszív szerepét egy aktívabb tágulással helyettesítette és ezzel a földi jelenségrendszer energiahátterét egy dinamikusabb elképzelésbe helyezte. Ezzel Egyed mintegy a lemeztektonika és geodinamika elôfutárának tekinthetô.”

Sikabonyi László, Kanadában élô magyar származású geológusnak az Alkalmazott Földtani Tanszékhez írt levelébôl is idéz Barta: "Talán jó megjegyezni, hogy Egyed László elméletei az izosztázia és kéregblokkok vándorlására nézve egész szép figyelmet kapnak az amerikai irodalomban, ami annál is meglepóbb, mivel az amerikaiak általában nagyon kevés külföldi nézetet ismernek el. Szerintem nagyon jó lenne Egyed László összes munkáit és jegyzeteit összeszedni és komolyan átvizsgálni. Úgy néz ki, hogy az újabban népszerúvé vált „plate tectonique”nek Egyed az egyik lényeges konceptuális megalapítója vagy szerzóje».

„Nézzük meg ilyen szempontból Egyed egyik elgondolását” - folytatja Barta. „Egyed a tengerpartok vidékén, az izosztatikus úszás következtében fellépó forgatónyomatékot tételezett fel, amely a kontinensek lemezeit a széleken bizonyos mértékig torzítja. Ebból az elgondolásból rendkívül csekély kiegészítéssel a lemeztektonika alapábráját nyerhetjük. Nem sokkal halála elótt Egyed az akkor még ismeretlen hot-spot jelenséget is elég egyértelmúen elôre jelezte.

A lemeztektonika fogalomkörében persze a tágulás vagy zsugorodás - esetleg pulzálás - az újonnan képzôdố és elnyelốdô kéreganyag arányától függ. Ezért jelenleg nem foglalkoznak részletesen a térfogatváltozás kérdésével. Ez a probléma a lemeztektonika kezdeténél mint indító tényező szerepelt és újból élesen jelentkezni fog teljes kifejlődésének idôszakában.”

Ha csupán néhány tanulmánnyal kellene Egyed földtágulási hipotézise fejlôdésének legfontosabb állomásait bemutatnunk az idôben, talán az alábbi évszámokkal jelzett publikációit érdemes megemlíteni (Egyed
1955, 1958, 1959, 1969). Azonban nagyon világos, tudományos igényú, népszerú áttekintést kaphatunk Barta (1970) tollából is, közvetlenül Egyed halálát követôen. A Magyar Tudományban megjelent nekrológjában pedig így ír Barta (1970a):

„Egyed elmélete szerint a Föld fizikai szerkezetét és fejlôdésének fô vonalát - kialakulását is beleértve a tágulás determinálja. Minden földtani-geofizikai ún. nagyjelenségnek - mint például a kontinensek és óceánok kialakulásának, a kontinensek vándorlásának, az óceánok fenékmozgásának - oka közvetlenül vagy közvetve a Föld tágulásában keresendô.

A kontinensvándorlás elvét alátámasztó az utóbbi években nyert paleomágneses mérési eredmények, valamint az óceánfenék idôbeli tágulásának mágneses mérések útján való meghatározása az Egyed-féle elmélet újabb erôs bizonyítékai, úgyhogy elmondhatjuk, hogy életmúvének legfontosabb központi alkotása - a Föld expanziós elmélete - még az alkotó életében az igazság rangjára emelkedett."

Tíz esztendôvel Egyed halála után, a Magyar Tudományos Akadémián még emlékülésen méltatták tudományos eredményeit, s Barta (1981) úgy szól életútjáról, hogy azt „Egy tudományág szinte megalapításától a nemzetközi tekintélyig vezetô múvelése" jellemzi.

Aztán újra megismétlôdött - bár nem oly deklaratív módon - a korában idézett 1926-os történet: a földtágulás elméletének csendes elhallgatásának idôszaka következett. A lemeztektonika fejlődésének egymást sû́rún követô, kézzel fogható eredményei feledtették a hipotézist. Csak néhány „kétkedô” folytatta a kutatásokat, a bizonyítékok gyưjtését, ahogy azt például Völgyesi Lajosnál (2005, 2006) láthatjuk: „A Föld tágulásának hipotézise alapvetôen Egyed László nevéhez fúzốdik, akinek ez az elképzelése ma még nem bizonyított, pontos és minden apró részletre kiterjedố igazolása a jövố egyik nehéz feladata... Egyed számításai szerint... mintegy 4 milliárd évvel ezelôtt a Föld sugara 3500-4000 km lehetett, 
ezért 4 milliárd év alatt a sugárnövekedés kb. 2500 km, azaz évente közel 0,6 mm. Egyed és Carey egyéb földtani vizsgálatok során hasonló értékeket kapott.

A vertikális gradiens normálértékével számolva az éves $0,6 \mathrm{~mm}$ sugárnövekedés a nehézségi gyorsulás csaknem $0,2 \mu \mathrm{Gal}$ nagyságú éves csökkenését eredményezi. Ez pedig azt jelenti, hogy a Föld sugarának növekedése a ma rendelkezésre álló mûszerekkel megfelelô mérési módszert alkalmazva egy-két évtizedes ismételt mérések során kimutatható lehet, amennyiben más egyéb gravitációs hatásoktól külön tudjuk választani."

A sors különös véletleneket produkál. Az 1980-as évek közepén újra „összehozott” Egyed Lászlóval. Földtágulási elméletének egyik alappillérét, az 1955-ös ún. asztrofizikai földmodelljét - amely a földbelsố szerkezeti felépítését mutatja be, és értelmezi annak a Föld tágulása szempontjából fontos folyamatos átalakulását - ábrázoltuk a Hajdu Lajos debreceni földrajz tanár megálmodta $40 \mathrm{~cm}$ átmérôjû́ szétszedhetô szerkezeti-morfológiai földgömb egyik metszetén (2. ábra). A glóbusz kiadástörténetérôl folyóiratunk korábbi számaiban már olvashatott az érdeklôdô (Márton 1988, 2020), a Virtuális Glóbuszok Múzeumában (http://terkeptar.elte.hu/vgm) pedig mind a magyar (VGM ID 8, 9, 10), mind az angol (VGM ID 66,67, 68) kiadását tanulmányozhatja. A Kossuth Lajos Tudományegyetem és az Eötvös Loránd Tudományegyetem, valamint a Kartográfiai Vállalat és a
Tanszergyártó és Értékesítô Vállalat együttmûködése eredményeképpen született glóbuszok máig az egyetlen hazánkban szerkesztett és kiadott tematikus „földgömbcsalád” tagjai.

\section{Két tudós elme szakirodalmi találkozása}

Lépjünk vissza néhány esztendôt az időben...

Kádár (1959) - Egyed Földrajzi Közleményekben megjelent tanulmányához írt - korreferátumában vázlatosan ismerteti azokat a kísérleteit, amelyek a földtágulás és a kontinensvándorlás összefüggésének bizonyítására, megszárított gipszkéreggel bevont felfújható gumilabdákon végzett. Ezeket tovább fújva vizsgálta a gipszkéreg felhasadásait és az így keletkezett kéregrészek egymástól való eltávolodását. Megkísérelte a Föld eredeti kérgét (archigaea) a mai kontinensek és selfek, valamint a Csendes-óceán szima-anyagú fenekének alapulvételével egy megfelelôen kisebb gömbön helyreállítani. Az eredeti földfelületet egyenlónek vette a mai kontinentális területek felületének és a csendes-óceáni bázikus fenék felületének az általános felületnövekedés arányában csökkentett terület-összegével. Az eredeti földsugarat így $4880 \mathrm{~km}$-nek kapta. Az ismertetett kísérletek jól mutatják a debreceni professzor földtágulással kapcsolatos, a budapesti professzorral azonos meggyőzódését. Kádár utal arra is, hogy Egyed kérésére megpróbálta a kérget egy akkora gömbön is összerakni, amelynek a felülete a mai szárazföldi területek felületével azonos, ám ez a kísérlet nem hozott elfogadható eredményt. Oly erôs Kádár földtágulással kapcsolatos meggyôzôdése, hogy ex-librisében is visszaköszön (3. ábra)

Ezeknek a kísérleteknek a leírásával, illetve említésével több helyen is találkozhatunk a szakirodalomban. Kádár (1963) egy hosszabb lélegzetú tanulmányát ismertetve Bendefy (1964) is utal ezekre, és Kádár egy érdekes következtetésérôl is beszámol: "Ez a meggondolás vezette Kádárt a kísérleti gumilabdákhoz. Kísérletei során, amelyekrôl „Erdausdehnung, Polwanderung und Klima (1962)" c. dolgozatában részletesen is beszámol, számos esetben olyan alakzatokat hozott létre a labdákat borító gipszrétegen, amelyek élénken emlékeztettek a kontinensek mai alakjára, ill. a Csendes-óceán medencéjének formáira. Az a kérdés, hogy hova lett a Csendes-óceán fenekéről hiányzó kéregrészlet, vezette Kádárt a Hold-képződés problémájához. ... Kiszámítja ugyanis, hogy amennyiben a Hold, a Pickering-féle elgondolásnak megfelelően, a Csendes-óceán mai térségébôl szakadt ki, akkor a Sial-kéreggel együtt még mintegy 150-165 km vastagságú Sima-rétegnek is ki kellett repülnie, hogy létrejöjjön a Holdat alkotó tömeg, mégpedig olyan 3,33-3,35 körüli fajsúllyal, amely mindkét feltételnek megfelel."

Kádár (1972) maga is vissza-viszszakanyarodik a témához, elhelyezve azt az „új” tudományos szintézis, a "geonómia” területén, mint például a Magyar Földrajzi Társaság alakuló közgyưlésévek 100. évfordulóján, annak elnökeként.

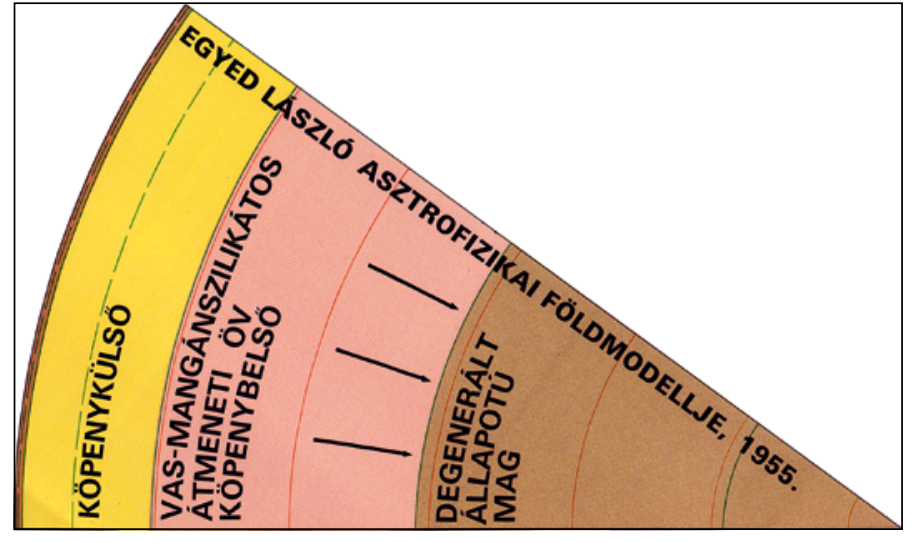

2. ábra. Egyed László asztrofizikai földmodelljének bemutatása a $40 \mathrm{~cm}$ átmérôjû́ szétszedhetố szerkezeti-morfológiai földgömb egyik metszetén

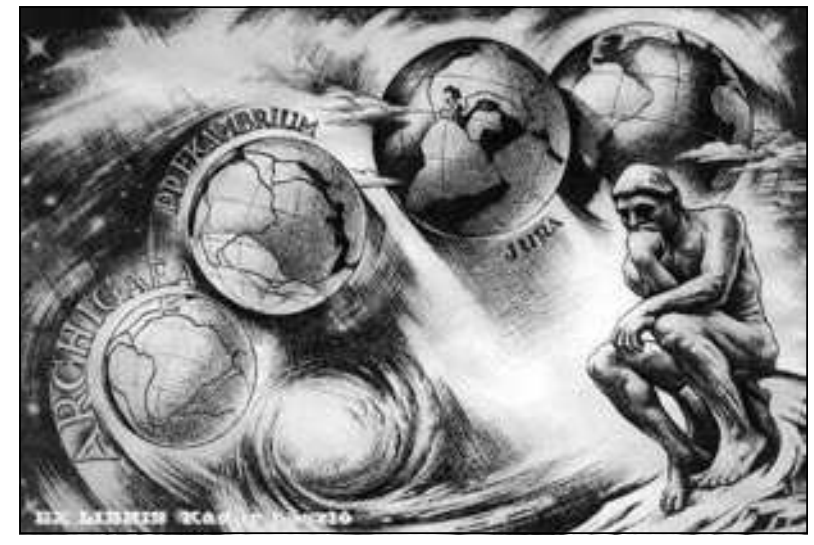

3. ábra. Kádár László ex-librise a „Geographia generalis et specialis"címú kötet borítóján. (Rajzolta: Bars László) 
Még külföldön is, másoknál is és idôben késôbb is elô-elôkerül a téma: Nem sokkal Egyed halálát követôen, 1976-ban Samuel Warren Carey (1911-2002) tasmániai professzor - erôsen támaszkodva Egyed publikált elképzeléseire - könyvet írt „The Expanding Earth" címmel (Elsevier Scientific Publishing Company, Amsterdam, The Nederlands) (Völgyesi 2020).

Kádár „...teljesen új területként a magyar geográfiában komoly előzmények nélkül - kezdte el a Föld mint égitest fejlôdésére irányuló kísérletes kutatásait (a földtágulás kérdéséról, a földforgás okairól, a kontinens- és pólusvándorlásról, s az azzal kapcsolatos éghajlatváltozásokról, a globális földi légkörzésrôl)" (Szabó 2008).

„Kádár László igen széles látókörû és rendkívül impulzív kutató volt, a szorosabb értelemben vett földrajzon messze túlmutató vonatkozásokkal. Új elméleteit - amelyeknek mindig volt racionális, de nem mindig elegendô objektív érvvel alátámasztott alapja - a szakmai körökben rendre általános megrökönyödéssel fogadták, de szisztematikus bírálat helyett általában rövid elutasítás után nem, vagy alig foglalkoztak vele. Részben ez volt a sorsa az Egyed alapján földtágulással foglalkozó teóriájának is" írta Szabó József érdeklôdésemre.

»Annak idején én voltam Kádár László utolsó tanársegéde (1958-tól hallgatója, 1963-tól tanársegéde), de a gipszgömbös kísérletekrôl már én is „lekéstem”, és csak eredményüket láttam az irodalomban, ill. maradványait a Tanszék múhelyében. Kádár azonban késóbb is foglalkozott a földfejlôdés témájával, de akkor a tágulást már kiindulási alapként kezelte, és fôleg azt vizsgálta, hogy egy táguló Földön (és ha annak még a tengelyállása is változik) hogyan változnak, tolódnak el az éghajlati övek (vö. pólusvándorlást is). Az ezek kapcsán készült földgömbsorozat (vagy annak egy része) került a Földrajzi Múzeumba a Földrajzi Tanszékek új épületbe költöztetésekor. A költözés kapcsán némi anyag veszendôbe is ment, és a Tanszéken ma már csak mutatóban van 1-2 gipszgömb (Szabó 2020)."

\section{A glóbuszsorozat bemutatása}

Az elôzőekben idézett „gumilabdás” kísérleteit egyrészt „a tágulás felszíni tektonikai formáinak vizsgálatára" végezte Kádár (Szádeczky-Kardoss 1968, p. 289), s ezek eredményét egyik tanulmányában fényképsorozaton ma is láthatjuk (4. ábra).

Másrészt magának a földtágulásnak bemutatását is szolgálták - a felhasadó „kéregrészek” egymástól való távolodásával -, az egyre jobban felfújt labdákról készített fényképek sorozatával szemléltetve (5. ábra).

Az elméleti, kísérleti eredmények gyakorlatba történó átültetését mutatja az a földgömbsorozat, amelyet ma az érdi Magyar Földrajzi Múzeumban ốriznek. Összesen 13 gipszgömb szerepel itt ma - Kádár László hagyatékénak részeként - az elkészült sorozatból. A hozzájuk tartozó leírást sajnos nem ismerjük. Az adományozó a debreceni Kossuth Lajos Tudományegyetemrôl dr. Szabó József volt. A leltári számok tanúsága szerint 1994-ben kerültek a Múzeumba a glóbuszok, amelyek két állványon elhelyezett darabjait a 6. ábrán láthatjuk.

A glóbuszok közül ötöt, csökkenó átmérô szerint sorba rendezve, a 7. ábrasoron mutatunk be. Így - a szerző, Kádár professzor értelmezésének megfelelốen - a korban

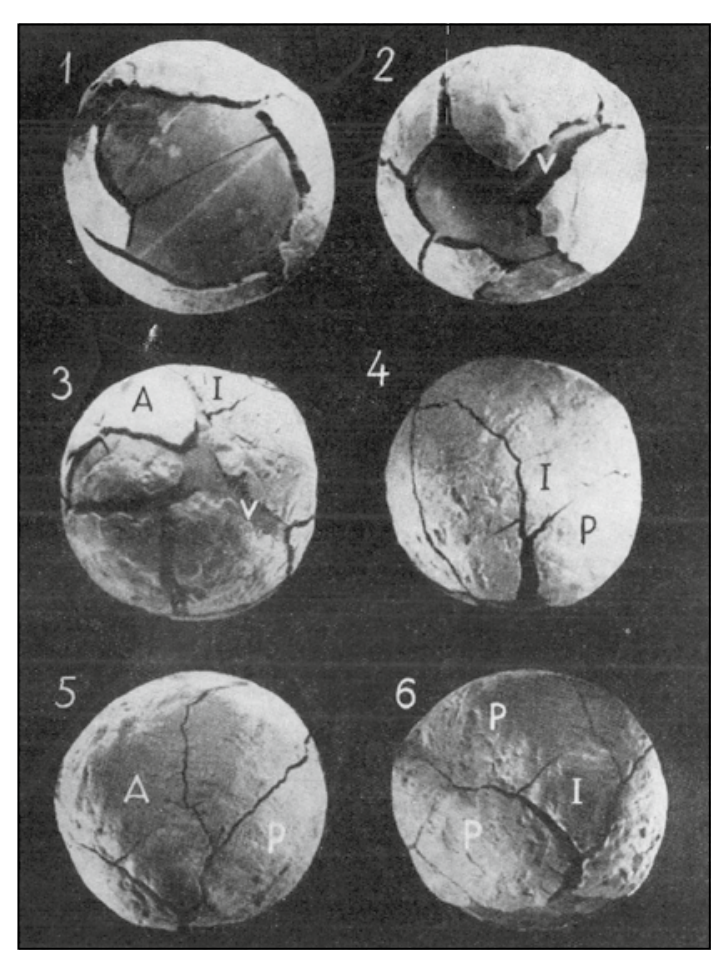

4. ábra. Kéregrepedések táguló gömbökön. A: Afrika-alakú, I: India-alakú, P: pajzsalakú kéregrészek; V: a Vörös-tengerre emlékeztetố repedések (Kádár 1959).

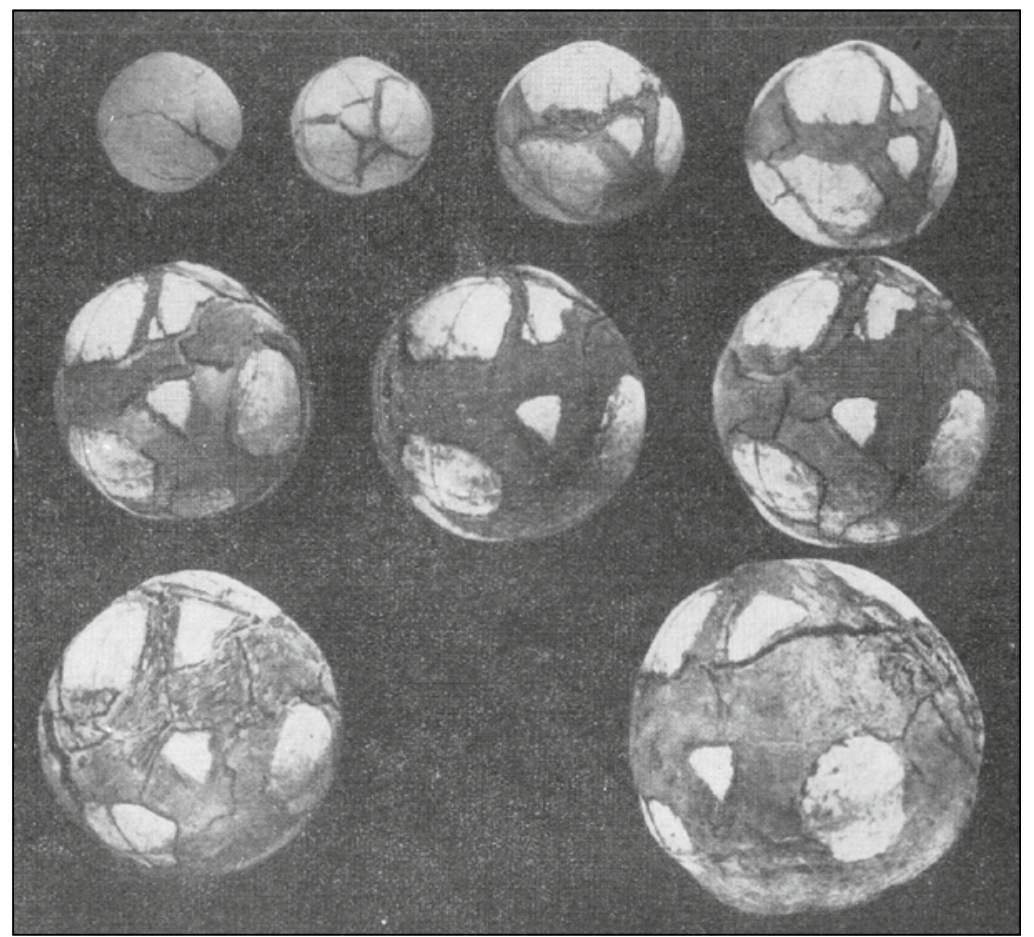

5. ábra. A „kontinensek” távolodása egymástól a táguló gömb felületén (Kádár 1959). 


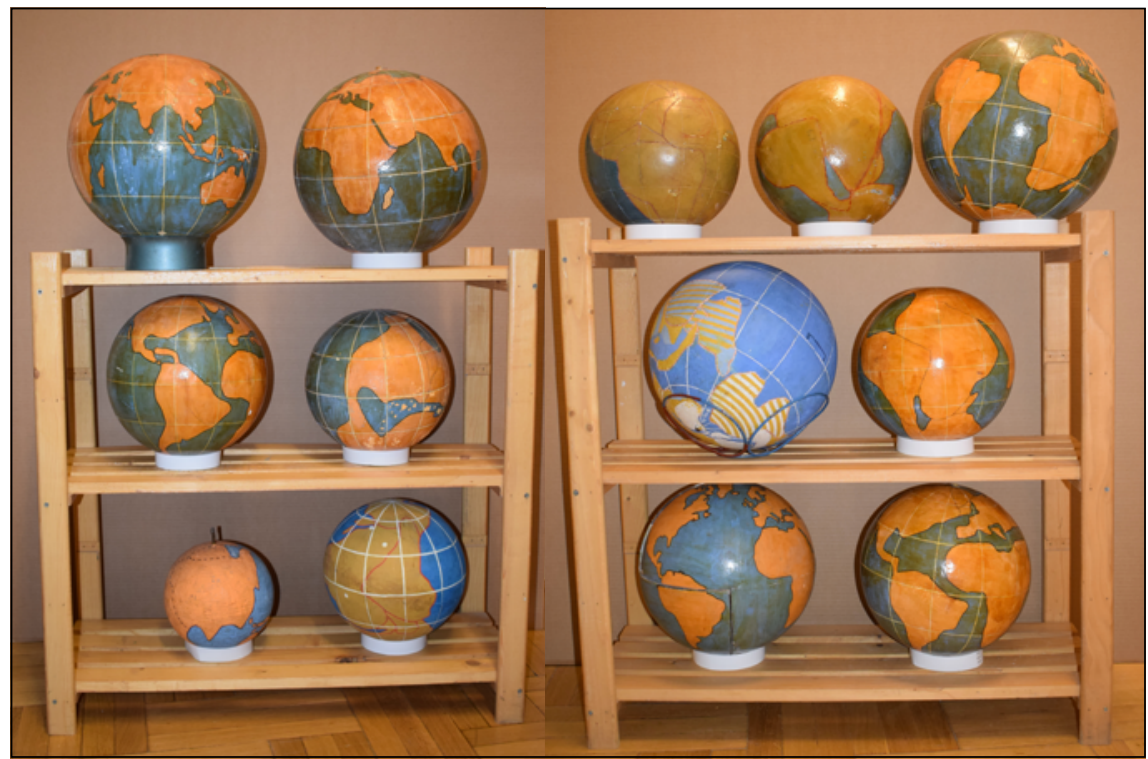

6. ábra. Az állványokra helyezett, Kádár László szerkesztette glóbuszok a Magyar Földrajzi Múzeumban, Érden (Fotók: Puskás Katalin)
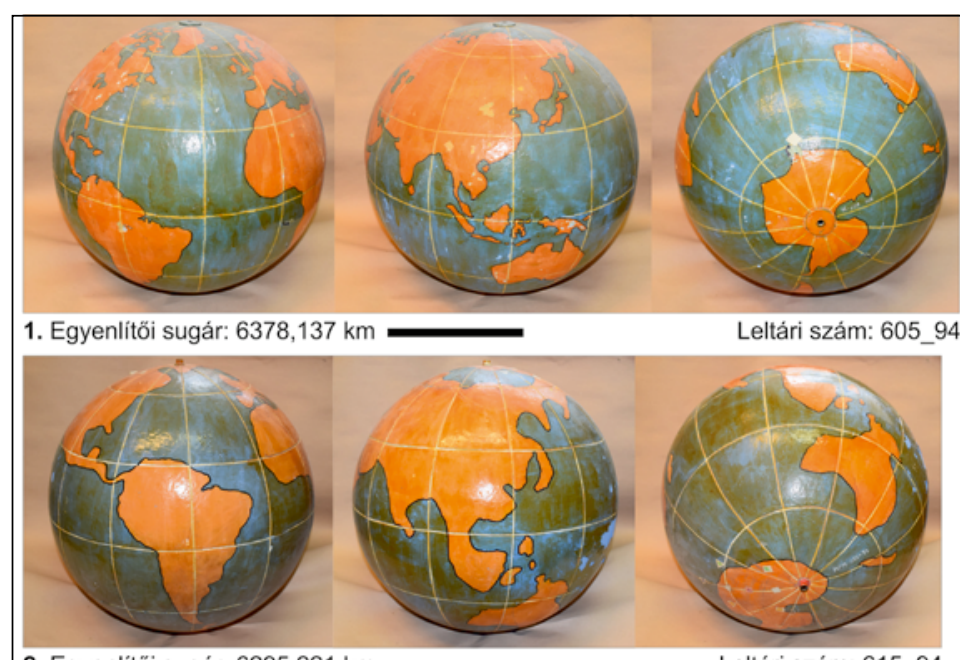

2. Egyenlítöi sugár: $6295,221 \mathrm{~km}$

Leltári szám: 615_94

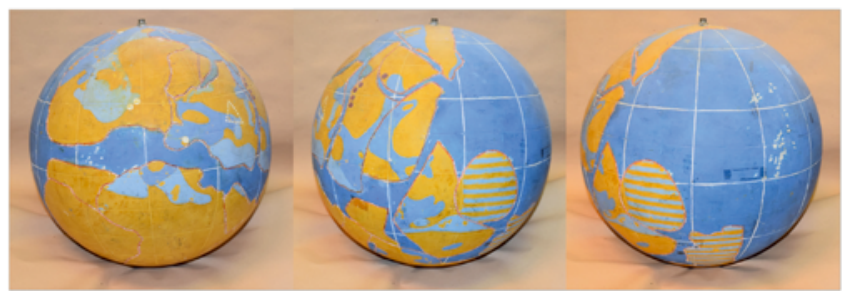

3. Egyenlítöi sugár: 5692,487 km

Leltári szám: 613_94
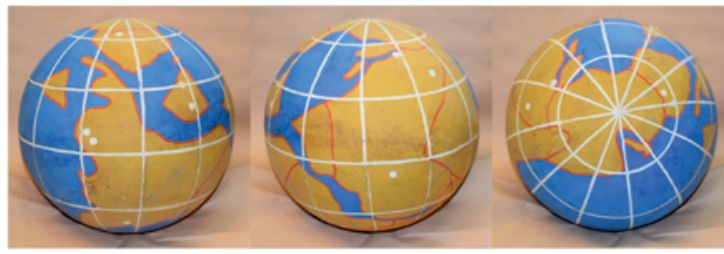

4. Egyenlítöi sugár: 5027,885 km
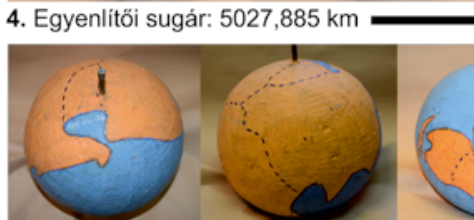

5. Egyenlítöi sugár: 3739,749 km

(a) haladva az idóben az egyenlitối sugár csökkenéséve

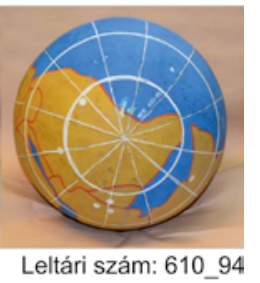

Leltári szám: 610_94

a Föld adott kori állapotát bemutató glóbuszok (Fotók: Puskás Katalin) visszafelé haladva egyre idôsebb állapotát láthatjuk Földünknek. A földgömbök adatai rendre a következők:

1. $30,7 \mathrm{~cm}$ átmérô, $6378,137 \mathrm{~km}$ egyenlítói sugár, $30^{\circ}$-os fokhálózat. Leltári szám: 605_94.

2. $30,3 \mathrm{~cm}$ átméró, $6295,221 \mathrm{~km}$ egyenlítói sugár, $30^{\circ}$-os fokhálózat. Leltári szám: 615_94.

3. $27,4 \mathrm{~cm}$ átmérô, $5692,487 \mathrm{~km}$ egyenlítói sugár, $30^{\circ}$-os fokhálózat. Leltári szám: 613_94.

4. $24,2 \mathrm{~cm}$ átmérô, $5027,885 \mathrm{~km}$ egyenlítói sugár, $30^{\circ}$-os fokhálózat. Leltári szám: 610_94.

5. $18,0 \mathrm{~cm}$ átméró, $3739,749 \mathrm{~km}$ egyenlítói sugár, fokhálózat nélkül. Leltári szám: 616_94.

Csak reménykedni tudunk abban, hogy a Kádár-hagyaték teljes feldolgozásakor világossá válik a gömbök felszínén megrajzolt jelek pontos értelmezése (valószínúsíthetố, hogy ezek a Föld mágneses pólusainak helyzetével kapcsolatosak), illetve a professzor úr által használt forrástérképek és leírások eredetére is fény derül.

A hagyatékból még egy érdekes földmodellrôl kell beszámolnunk. Kádár nemcsak a földtágulással, hanem a Föld belsô szerkezetével is foglalkozott. A 8. ábrán sajátos „drótmodellt" láthatunk.

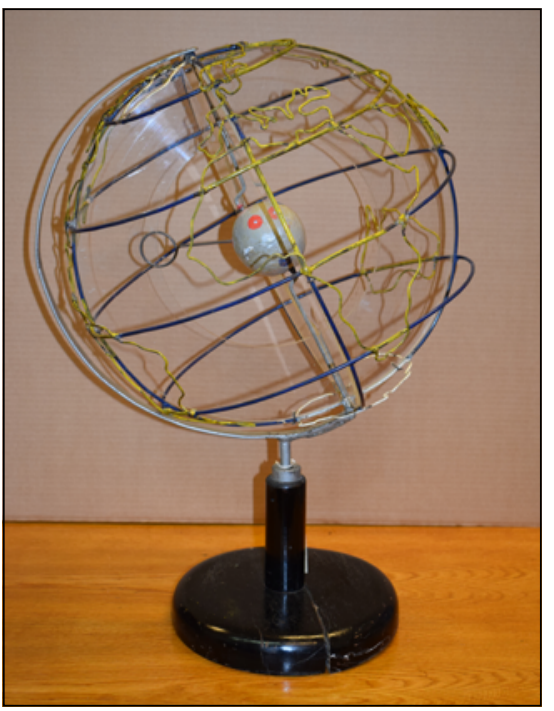

8. ábra. A Föld belsố szerkezete (Fotó: Puskás Katalin)

A drótgömböt a fekete, lakkozott faállványon egy ezüstszínúre festett fél meridiánkör tartja. Az Egyenlítô, a térítôk és a sarkkörök, 
valamint az ezeket egymáshoz rögzítő meridiánkör, a tengeri területeken sötétkékre, a szárazföldeken sárgára, az állandóan jéggel fedett területeken (Grönland, Antarktika) fehérre festettek. Az ezüstszínú belsố mag excentrikus elhelyezkedését az ezüstszínú „megtört” földtengely mutatja. A földbelsố további öveinek szemléltetését egy plexi metszet szolgálja. A külsô mag „üres”, az alsó és a felső köpeny határát a plexin megrajzolt halványbarna vonal jelzi.

\section{Köszönetnyilvánítás}

Köszönettel tartozom az érdi Magyar Földrajzi Múzeum munkatársainak, dr. Kubassek János igazgató úrnak és Puskás Katalin tárgyrestaurátor múvész - gyújteménykezelônek nagyvonalú segítségéért, amely lehetôvé tette e dolgozat publikálását a Geodézia és Kartográfiában. Puskás Katalinnak külön is megköszönöm a fényképek elkészítését ebben a „vesztegzáras" idôszakban.

Köszönet jár Szabó József és Völgyesi Lajos professor emeritus uraknak, akik készséggel válaszoltak szakmai kérdéseimre.

\section{Irodalom}

Barta György 1966. A geodéziai-geofizikai földgömb tervezete. Kézirat, ELTE, Budapest

Barta György 1970. És mégis tágul a Föld... Egyed László elmélete. Élet és Tudomány, 48. szám, pp. 2284-2288.

Barta György 1970a. Egyed László $1914-$ 1970. Magyar Tudomány, LXXVII. kötet. - Új folyam. XV. kötet, 10. szám, pp. 758-760.

Barta György 1978. Az általános geofizikai kutatás Magyarországon és a földtani nyersanyagkutatás. Magyar Geofizika, XIX. évfolyam, 1. szám, pp. 1-5.

Balkay Bálint 1979. Egyed László és a tektonika. Földtani tudománytörténeti évkönyv, 8. szám, pp. 165-181.

Bendefy 1964. lásd Kádár 1963
Egyed László 1955. A Föld belsố felépíté sének új elmélete. Földtani Közlöny, LXXXV. évfolyam, 3. szám, pp. 277-318.

Egyed László 1958. Continental drift polarwandering and the internal constitution of the Earth. A new conception of the Wegener-theory Acta Zoologica, III. kötet, 3-4. szám, pp. 201-204.

Egyed László 1959. Zsugorodás, tágulás vagy magmaáramlások? Földrajzi Közlemények, VII. (LXXXIII.) évfolyam, 1. szám. pp. 1-20.

Egyed László 1969. Physik der festen Erde. B. G. Teubner Verlagsgesellschaft, Leipzig - Akadémiai Kiadó, Budapest, p. 367

ELTE-01: http://geophysics.elte.hu/ inmemoriam/egyed.htm, utolsó elérés: 2020.11. 23.

ELTE-02: http://ishm.elte.hu/hun/dolgozo/ elhunyt/stegena.htm, utolsó elérés: 2020. 11. 23.

ELTE-03: http://geophysics.elte.hu/ inmemoriam/barta.htm, utolsó elérés: 2020. 11. 23.

ELTE-04: http://ishm.elte.hu/hun/dolgozo/ elhunyt/fusi.htm, utolsó elérés: 2020. 11. 23.

Füsi Lajos 1970. Production of Relief Maps and Globes from Plastic Materials. Hungarian Cartographical Studies. HNC-ICA, Budapest

Füsi Lajos 1973. Múanyag földgömbök és dombortérképek. Térképtudományi Tanulmányok, 4. kötet, ELTE, Budapest

Kádár László (1959) korreferátuma pp. 16-18. In Egyed László: Zsugorodás, tágulás vagy magmaáramlások? Földrajzi Közlemények, VII. (LXXXIII.) évfolyam, 1959., 1. szám. pp. 1-20.

Kádár László 1963. A földforgás okai és következményei. (Planetáris geográfiai vázlatok.) A Kossuth Lajos Tud. Egyetem Földrajzi Intézetének kiadása (rotaprint). 47 old. 15 ábra, Debrecen, 1963. Ismerteti: Bendefy László. In Földrajzi Értesító, XIII. évfolyam, 1964. 3. füzet, pp. 413-415.

Kádár László 1972. A geográfiáról és a geonómiáról. Földrajzi Közlemények, XX. (XCVI.) kötet, 4. szám, pp. 285-292.

Kenyeres Ágnes (fôszerk.) 1994. Magyar Életrajzi Lexikon, CD-ROM, Kádár László. https://www.arcanum.hu/hu/onlinekiadvanyok/Lexikonok-magyar-eletrajzilexikon-7428D/k-760F2/kadar-laszlo7611A/, utolsó elérés: 2020. 11. 23.

Márton Mátyás 1974. A Pannon-medence tektonikája. Diplomadolgozat. Kézirat, ELTE, Budapest

Márton Mátyás 1975. Geofizikai földgömbök szerkesztése. Diplomadolgozat. Kézirat, ELTE, Budapest
Márton Mátyás 1985. Az óceán-és tengerfenék domborzata. Tenger alatti felszínek ábrázolása kisméretarányú térképeken. Egyetemi doktori disszertáció. Kézirat, ELTE, Budapest

Márton Mátyás 1988. A Kartográfiai Vállalat földgömbjei. Geodézia és Kartográfia, 40. évfolyam, 1. szám, pp. 42-48.

Márton Mátyás 2020. Új, orosz nyelvû szerkezeti-morfológiai földgömb a Virtuális Glóbuszok Múzeumában, és ami mögötte áll. Geodézia és Kartográfia, 72. évfolyam, 3. szám, pp. 4-11. DOI: $10.30921 / \mathrm{GK} .72 .2020 .3 .1$

Márton Péter 1981. Egyed László tudományos munkássága. Az MTA Föld-és Bányászati Tudományok Osztályának Közleményei, 14. kötet, 2-4. szám, pp. 353-357.

Olajos Eszter 1974. A tematikus múanyag földgömbök kartografálása. Diplomadolgozat. Kézirat, ELTE, Budapest

Szabó József 2008. Kádár László életmúve különös tekintettel természetföldrajzi munkásságára pp. 11-25. In Geographia generalis et specialis. Szerk: Szabó József, Demeter Gábor, Debreceni Egyetem Kossuth Egyetemi Kiadója, 2008, p. 410

Szabó József 2020. Szóbeli közlés

Szádeczky-Kardoss Elemér 1968. A Föld szerkezete és fejlốdése. Akadémiai Kiadó, Budapest, p. 340

Völgyesi Lajos 2005. A nehézségi erôtér idôbeli változása. Geomatikai Közlemények /Publications in Geomatics 8, pp. 179-190.

Völgyesi Lajos 2006. Some possible physical reasons of time variation of Earth's gravity field (a possible proof of time change of gravitational constant) Periodica Polytechnica Civ. Eng., 50 (2), pp. 161-170.

Völgyesi Lajos 2020. Szóbeli közlés

Wikipédia-01: https://hu.wikipedia.org/ wiki/Horv\%C3\%A1th Ferenc (geofizikus), utolsó elérés: 2020. 11. 23.

Wikipédia-02: https://hu.wikipedia.org/ wiki/G\%C3\%A9czy Barnab\%C3\%A1s, utolsó elérés: 2020. 11. 23.

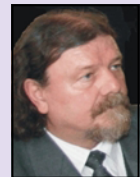

Dr. Márton Mátyás professor emeritus

ELTE Térképtudományi és Geoinformatikai Intézet matyi@map.elte.hu 